\title{
The life cycle of the range condition concept
}

\author{
LINDA A. JOYCE
}

Author is range scientist, USDA Forest Service, Rocky Mountain Forest and Range Experiment Station, Fort Collins, Colo. 80521 .

\begin{abstract}
Recent concerns about range condition measures are not the first concerns about measuring the health of rangelands. To examine why change has not occurred in this area, this paper explores the historical development of the range condition concept in the context of the life cycle of a scientific theory. Dyksterhuis' contribution and significant impact on the concept of range condition reflects the close tie between an underlying ecological theory of the time, that grazing alters species composition in a predictable manner, and his field method which measured that change as the difference between the relative composition of the current and climax vegetation. The evolution of the range condition concept differs in significant ways from the evolution of scientific theories such as Clements' climax theory. These differences include the lack of an intellectual center for research on range condition and reflect the institutionalization of technology to measure range condition. Success of alternative models for range condition may require an underlying theory linked to $a$ field method to successfully capture the consensus of the range community.
\end{abstract}

Key Words: history of science, range health, succession, climax, multiple steady states

Recent interest in the assessment of rangeland health has lead to the establishment of 2 committees with the objective of improving rangeland inventory measurements (Busby 1991, Smith 1991). These committees are not the first to raise concerns about the health of rangelands, inventory methods, or the measurement of range condition (GAO 1982, Smith 1896, U.S. Senate 1936). Yet amidst these concerns, the range science and management community continues to teach range condition measures (Heady 1975 , Stoddart et al. 1975) and to use range condition as the standard for health (USDA SDS and Iowa State Univ. Statistical Lab. 1987, USDI BLM 1988). Why did recommendations of earlier committees not initiate change, if change was prescribed? Why has the

\footnotetext{
Rudy King conducted the statistical analysis and Bob Dana contributed the computerized literature search.

Manuscript accepted 15 Aug. 1992.
}

concept of range condition been retained within the range science and management community for so long, if change is needed?

Philosophers of science espouse the idea that scientific knowledge progresses, not as a simple aggregation of objective statements, but rather by the complete abandonment of earlier theories and the adoption of a new theory or model (Crane 1972). While we sometimes think of theories as all encompassing, such as a unified field theory in physics, the diversity of different research fields within a major area of research reflects different theoretical models. Ideas are born, cast into the investigative milieu, mature, and, in dying, give birth to new scientific ideas. This life cycle of ideas has been given structure by historians of science. An analysis of the range condition concept, as a scientific idea, may offer insight into the historical role of change in the development of the range condition concept. This paper will review the life cycle of the climax and succession theory developed by Clements (1916) and examine the historical development of the range condition concept. Implications to the evolution of the range condition concept will also be addressed.

\section{Intellectual and Social Development of Research Fields}

Crane (1972) described the development of a research field as a 2-step process: (1) the development of an "innovation," either theoretical as in the postulation of a theory or technical as in the development of a new technique, and (2) the diffusion of this innovation to other scientists. The innovation is contrary to current theories or accepted models within the discipline and, as such, represents a discontinuity in the development of the current major theories. The innovation represents "a novel orientation toward the phenomena and a new methodology for solving a class of problems" (Tobey 1981, p. 113). This contrary idea establishes tension within the field. The second step, the diffusion of this innovation, occurs through personal contact, instruction, establishment of training and degree programs, collaborative research, and publication.

According to Crane (1972), the intellectual development of a new research field involves 4 stages. Stage 1 is the period in which the innovation is first proposed and discussed within the scientific 
community. Within stage 2 , scientists tackle problems using the innovation. This period has been referred to as "normal science" and is usually initiated by the publication of a seminal work describing the innovation. Stage 3 reflects the period when some problems are solved and other problems (anomalies) appear that cannot be solved by the application of the innovation. In stage 4, the research field disappears, a result of increasing controversy associated with the anomalies, or exhaustion of the field's problems.

Paralleling the intellectual development is the social development of the research's field. Within stage 1 , the scientific community interested in this research is small and has little social organization. As more scientists investigate the innovation, groups of collaborators develop. This scientific network has been referred to as the invisible college, because institutional affiliation does not identify the research field. The institutional development is strongest within the normal science stage, stage 2 . Within stage 3 , the community fragments as problems are solved or not solved and, finally in stage 4 , the community disintegrates.

The pattern of these stages is reflected in the logistic curve of the cumulative number of publications within the research field (Crane 1972 , Tobey 1981). In stage 1 , publication output reflects the small size of the invisible college (Fig. 1). Within stage 2, increased

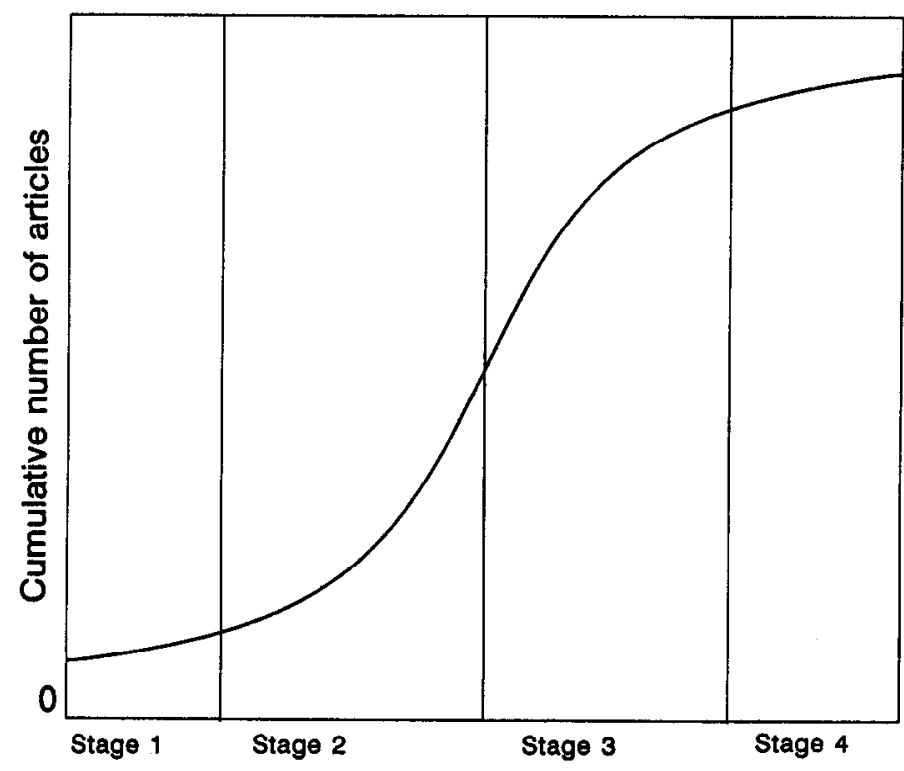

Fig. 1. Cumulative numbers of published articles associated with each stage in the life cycle of a research field (after Tobey 1981).

collaborations, graduate training, and general acceptance result in an exponential rise in numbers of publications. As problems are solved, fewer problems remain. Problems not solved increase controversy and disinterest in the innovation. The rate of increase in publications declines in stage 3. Finally, few publications appear in stage 4 as little research is undertaken.

\section{Intellectual and Social Development of Succession and Climax Theory}

Tobey (1981) described the life cycle of the climax theory of Clements using the above model. A brief characterization of the stages for this theory follows.

The Innovation; Stage 1

In the early 1900 's, Clements proposed that vegetation was dynamic, constantly changing, and, like an organism, reproduced, grew, matured, died, and reproduced itself. This theory contrasted to the then-prevalent view that vegetation was static and unchanging (McIntosh 1985). Clements (1905) also developed a field tech- nique where composition (number of individuals by species) and structure of the vegetation were recorded within a quadrat. The practice then current in field botany was to describe vegetation with species lists compiled during walks through large areas.

Clements and his major professor, Bessey, initiated a new way of synthesizing plant community dynamics (Tobey 1981). Tobey cited the start of this innovative period as 1895 , one year after Bessey arrived at the University of Nebraska. By 1916, many scientists who studied under Clements at the University of Nebraska were using his methods to discover ideas about natural ecosystems, publishing their research results (Fig. 2), and disseminating this scientific and methodological approach.

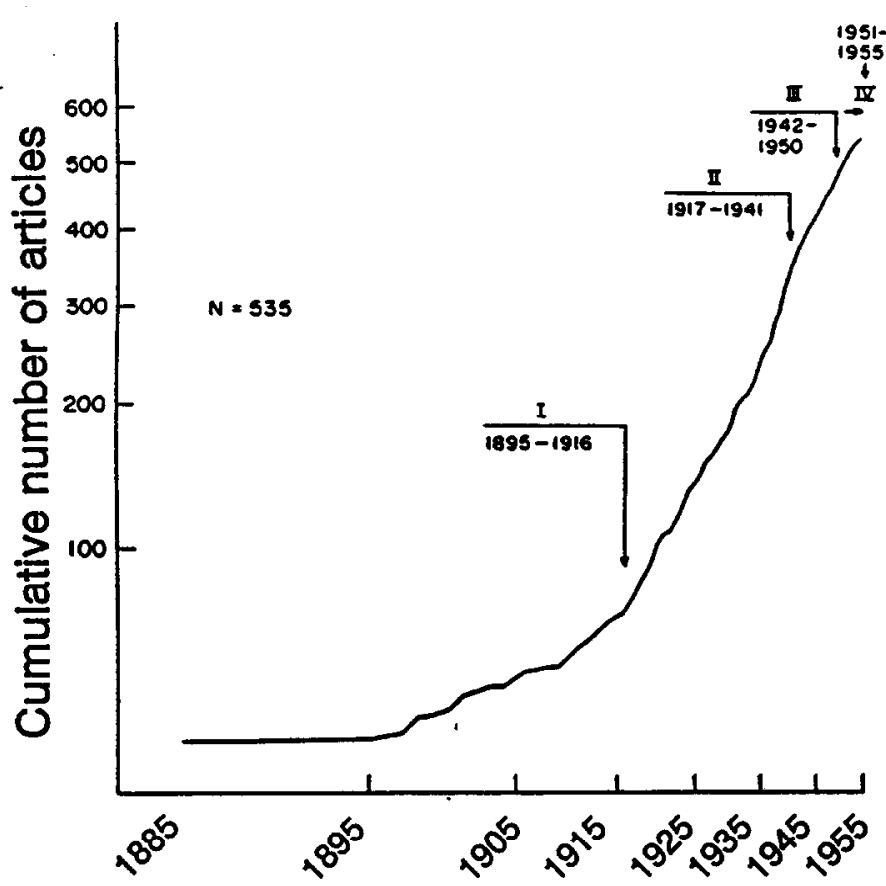

Fig. 2. Cumulative number of articles associated with the "climax" research field (after Tobey 1981).

\section{Normal Science; Stage 2}

In 1916, Clements published his seminal work entitled Plant Succession: an Analysis of the Development of Vegetation. His successional theory rested upon the assumption that vegetation could be classified into "formations" representing a group of plant species acting as an organic entity. The formation was "the climax community of a natural area in which the essential climatic relations are similar or identical" (Clements 1916, p. 126). All successional units within a region developed along 1 linear path toward a single formation, determined by the climate. This theory of vegetation dynamics has been referred to as the mono-climax theory.

In the innovation stage, the ideas were tied solely to Clements; in the normal science stage, these ideas diffused throughout the academic community. The University of Nebraska, even after Clements left, was the intellectual center for this theory (McIntosh 1985, Tobey 1981). Collaborative research efforts tied the University of Nebraska to other Great Plains schools such as Kansas State College and North Dakota Agricultural College. The influence of Great Plains researchers on the development of these successional ideas increased over the 1917-1941 period of normal science: they authored less than half of the most often cited literature of the early part of this period (1916-1929) but nearly $75 \%$ of the most often cited grassland ecology literature in the latter part (1929-1949).

Tobey (1981) describes the community associated with the normal science period as "tradition oriented, noncritical, closed to new 
ideas." While collaboration diffuses the new idea and method into the academic community, collaboration also indicates who is a member of the invisible college. By looking at authorship and citation patterns, Tobey draws a picture of a closed network. Of all multiple-authored papers, $42 \%$ were co-authored by F. Albertson, F. Clements, H. Hanson, or J. Weaver. Of all grassland ecology papers, $33 \%$ of all citations were to scientists within this field. Major external critics, such as Tansley at Oxford University and the plant sociologists of the Braun-Blanquet School, were not cited (Tobey 1981). This research community was primarily a selfreferencing and inward-looking group.

\section{Competing Theories; Stages 3 and 4}

While Clements theorized that climate alone controlled climax, other scientists questioned the narrowness of this mono-climax description of a stable community. As early as 1911 , Cowles criticized Clements' theory of primary succession (newly formed soils) versus secondary succession (denuded soils) as lumping similar causal factors. After extensive study of the tropical montane forest, Shreve (1914) argued that there were no means to determine which habitat was in the closest "adjustment to its own complex of physical conditions," the regional "climax." Gleason (1917) criticized the concept that a unit of vegetation was an organic entity. In 1920 , Tansley could not accept the assumption that edaphic factors cannot determine climax.

Tobey (1981) demarcates stage 3 as the period 1942-1950 and stage 4 as 1951-1955 (Fig. 2). Even though external criticism had greatly undermined Clements' theory by the 1950's, Tobey ascribed the final demise to Great Plains scientists reporting the inability of Clements' theory to predict the consequences of the 1930's drought on the Great Plains.

In the external criticism of the climax theory during the late 1940 's and early 1950's, there were the beginnings of new theories on succession and community dynamics. The frustation of community ecologists with then-current theory was expressed in 1947 by A.S. Watt (quoted by McIntosh 1985, p. 106), "It is now a half century since the study of ecology was injected with the dynamic concept, yet in the vast output of literature stimulated by it there is no record of an attempt to apply dynamic principles to the elucidation of the plant community itself and to formulate laws according to which it maintains and regenerates itself." However, in 1953, Whittaker would cite more than 17 papers on divergent interpretations of climax and succession. The external criticism suggested change in the climax theory, the internal research suggested change, and by the mid-1950s, community ecologists had left Clements' climax theory and were testing alternative theories.

\section{Intellectual Development of the Range Condition Concept}

Succession as a Factor in Range Research; The Innovative Period

The first published reference to the utility of successional stages in range management was the paper read before the Botanical Society of Washington, D.C., 1 year after the appearance of Clements' seminal publication. In this paper, Sampson (1917) described knowledge of succession as "well nigh indispensable to the working out of a judicious system of management" (p. 596). Sampson (1919) described how successional stages could be used to detect overgrazing, what plants were reliable indicators of overgrazing, and how these indicators could be used as guides in revegetation and the maintenance of forage. He tied successful revegetation to the degree of depletion of the soil, as long as other conditions remained constant, and cautioned that succession was best promoted by a grazing plan based on "the life history of the different species, and notably upon the time of seed maturity" ( $p$. 7).

This application of successional theory allowed range scientists, much as it did grassland ecologists, to study the influence of grazing on plant communities within a theoretical framework. Clements (1916) identified livestock grazing as a factor initiating plant invasion and the processes of plant succession. Sampson (1923) went on to identify research areas important in understanding how grazing could be used to promote succession of range ecosystems: (1) the reproductive ecology of dominant plant species, including aggressive invaders; (2) the competitive ability of plants to establish soil cover under different grazing methods and without grazing on similar lands; (3) potential forage yield; (4) yearly variation in the productivity of the different vegetation types; and (5) the effects of different methods of handling the stock on successional replacement of undesirable (nonpalatable and poisonous) plants by palatable, nutritious, and high-yielding species, preferably perennials. These ideas of Sampson and the collaborative work of grassland ecologists such as Albertson and Weaver and with range scientists (Wasser 1977) fostered the development of a range research community studying succession, the use of indicator species, and the influence of grazing on rangeland vegetation (Albertson 1937, Ellison 1949, Forsling 1931, Hanson and Whitman 1938, Hanson et al. 1931, Humphrey 1949, Humphrey and Lister 1941, Reid and Pickford 1946, Sampson 1919, Sarvis 1920, Stoddart 1935 as referenced in Spence 1938, Weaver and Fitzpatrick 1932).

Attempts to formalize the relationship between grazing and succession led to the development of terminology and methodology specific to rangelands. In the late 1930 's, Stoddart used the term "vegetative condition class" to describe successional stage (Spence 1938). McArdle et al. (1936) summarized Forest Service data using 4 range depletion classes, where depletion was relative to pristine range conditions. Attempts to officially define methods to determine range condition were made by the Interagency Range Survey Committee in 1937. The Committee adopted the range reconnaissance method of range survey, and numerous surveys were made during 1938 using this method. Disenchantment within the Soil Conservation Service (SCS) with this method initiated the development of other methods (Helms 1990). Within the Pacific Coast Region of the SCS, guides to determining range condition had been published for 16 different vegetation types by 1948 . Condition class rating was defined on the basis of similarity to potential forage yield, composition of forage plants within 3 groups (desirable, less desirable, and undesirable), amount of litter, and erosion condition (e.g., Clark 1948). By 1949, Dyksterhuis complained that "there are many different bases for range condition classification" and that "some no longer have the original ecologic basis." The technical aspects of inventorying range health shifted the focus from the ecology of range ecosystems to techniques of measuring change.

\section{A Seminal Paper by Dyksterhuis; The Normal Science Period}

Dyksterhuis (1949) described a quantitative approach for assessing range condition. The standard for comparison was developed by establishing 3 classes of plant species (decreasers, increasers, invaders) based on their response to grazing. The relative composition of the 3 classes shifted as the vegetation regressed from climax to a disturbed state. Relative coverage of plant species within these 3 classes was estimated in the field and compared to standard cover values for that location. Different sites required different standards for comparison.

The critical differences in approach between this paper and earlier papers attempting to quantify the condition of rangeland were that all plant species could be grouped as to their response to grazing and the temporal change of these groups was continuous and measurable. According to Dyksterhuis (1949), his range condition concept differed from other current ideas because: 1) site classification was not dependent upon current vegetation; 2) forage 
production was considered a basis for range condition classification; 3) empirical groups of plants were replaced with an ecological classification, and 4) the widely used concept of forage density was replaced with "the quantitative relations of vegetation based on total annual forage production."

Dyksterhuis incorporated not only successional theory into his concept of range condition, but also research on plant indicators. He broadened the idea of climax beyond that of Clements (1916) to include edaphic or physiographic climaxes (Dyksterhuis 1958). He referred to the different climaxes as "sites," and the term "range site" came to be associated with different types of climax vegetation. While individual plant indicators had long been associated with certain successional stages, he offered a simplication: 3 kinds of species within the plant community, that were of distinctly different value to grazing managers.

Holechek (1981) described the appearance of Dyksterhuis' paper as one of the 3 most important events that occurred during the 1940 's in range management, stating that this paper influenced range management theory more than any other single publication. No other definition or explanation of range condition was as explicit or reproducible in the field. For instance, early guides by the Pacific Coast region of the SCS separated classes by highly qualitative differences, such as "rather heavy invasion" to represent fair condition (Humphrey and Lister 1941). Later guides developed within this region quantified classes by the presence or absence of plant species desirable as livestock forage (e.g., Clark 1948). Ellison (1949) based range condition on soil stability and floristic composition, but did not offer a quantitative field method. The ties to the ecological literature and the quantitative aspect, as well as its use in the 1930's and 1940's by Oklahoma and Texas SCS conservationists (Dyksterhuis 1949), led to widespread acceptance of Dyksterhuis' definition of range condition.

The publication of Dyksterhuis' 1949 paper signals the end of the innovation period, stage 1 , in which the idea of range condition was proposed, and the beginning of the normal science period, stage 2. Publications after 1949 and into the late 1960's explored the relationship between range condition and insects (Nerney 1958), runoff (Leithead 1959), plant vigor (Goebel and Cook 1960), livestock production (Cook et al. 1962), grazing management (Valentine 1967), and wildlife management (Berg 1966). More than just a methodological technique to determine overgrazing, range condition was used as a stratification of the ecosystem in order to test whether hydrological, botanical, or physiological aspects differed across condition class.

The late 1940's and early 1950's have other characteristics of normal science. The range condition concept was presented in the first range textbooks (Sampson 1952, Stoddart and Smith 1943). These first editions reference papers leading to the development of range condition and range site concepts but do not mention the papers critical of successional theories or climax, on which the concept rested (Smith 1989). This inwardly looking omission is typical of the normal science period. It is ironic that range scientists and managers were solidifying their use of climax while community ecologists were debating the very existence of community types and climax (e.g., Gleason 1939).

To examine the development of range condition as a research field after 1949, articles published within the Journal of Range Management (JRM) were considered a sample of the larger field of range research, and those articles in $J R M$ on range condition were taken to be indicative of the specialized field, range condition. Volume 1 was published in 1948, only 1 year before Dyksterhuis' seminal paper appeared. The 1948-1982 index and the annual indices from 1982-1990 were searched for articles with keywords "range condition." In addition, the titles of all articles were scanned for the words "range condition." The use of keywords and titles is similar to the methods of Tobey (1981)

A total of 78 articles was published in $J R M$ on range condition through 1990 (Fig. 3). More than half of these articles were published before the middle of the period, 1962. This rapid rise of

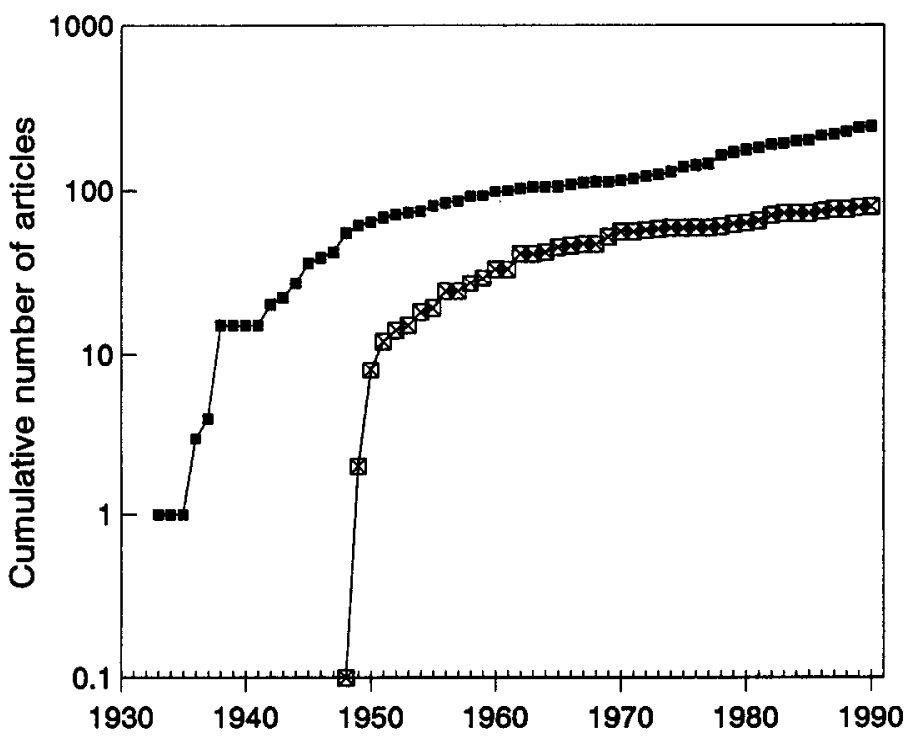

Fig. 3. Cumulative number of articles on range condition published in the Journal of Range Management (squares with $x$ 's) and in other sources (filled squares).

publications is typical of the normal science stage. A segmented regression model (Seber and Wild 1989) of number of articles published against year $r^{2}=0.994$ ) identified a significant break in the annual rate of publications in 1961. The slope over the 1948-1961 period was 2.51 articles year ${ }^{-1}$ and the slope over the 1962-1990 period was 1.30 . Perhaps stage 2 ended and stage 3 began in the early 1960's. No transition between stages 3 and 4 could be identified in the analysis; the slope of a 1980-1990 regression was not significantly different from either a 1962-1979 regression or the overall 1962-1990 regression. This raises the possibility that the changes in the field might not be reflected in $J R M$ or that the field has entered stage 4 (Fig. 3), considering also that number of publications increased slowly after the 1950's.

\section{Competing Theories; Stages 3 and 4}

Stage 3 should reflect fruitful research, or, at least, useful application of the range condition concept and, perhaps, the appearance of problems with the concept. Range condition was still being used as an organization construct in research after 1961 (e.g., Cook et al. 1962, Berg 1966). However, different schools of thought on range condition were evident by the mid-1950's (Costello 1956). Methodological concerns about the significance of erosion (Ellison 1949) and forage production (Humphrey 1949) in the determination of range condition were raised the same year Dyksterhuis' paper was published. By 1962, range condition methods were not discussed nor was Dyksterhuis' 1949 paper cited in a range reseach methods conference (Subcommittee on Range Research Methods of the Agricultural Board 1962). In another 1962 research methods conference, a committee report asked the question: "What attributes best express range condition and trend?" (USDA Forest Service 1963, p. 14), implying not only that no definite answer was known but that range condition was viewed as an expression of several attributes rather than species composition alone.

The decline in numbers of articles on range condition in JRM after 1961 may also reflect a shift in the focus of range research from describing the condition of range ecosystems to research on 
more intensive practices. The period in the late 1950's and 1960's saw much research on vegetation change and brush control, range fertilization, range seeding, range spraying, and other types of range improvement (Holechek 1981). It is possible that the vegetation changes resulting from these practices could not easily be described by a classification system designed to reflect successional change.

To determine if the 1961 decline in rate of publications was a specific to $J R M$, a literature search was made of other sources of articles on range condition. Again, the keyword "range condition" and titles were used to obtain articles. Computerized literature searches included Biosis (1969-1991), Agricola (1970-1991), CAB Abstracts (1972-1991), Life Sciences Collections (1978-1991), Agris International (1974-1990), Zoological Record (1978-1990), and Scisearch (1980-1986). For publications prior to the computerized database, I searched references in textbooks by Sampson (1952), Stoddart and Smith (1943, 1955); Current Literature as reported in $J R M$ over the 1961-1968 period; theses over 1955-1967 reported in JRM; indexes in Journal of Forestry (1902-1990), Ecology (1920-1990), Ecological Monographs (1931-1990), Journal of Wildlife Management (1937-1990), Agronomy Journal (1930-1990), and the Journal of Soil and Water Conservation (1946-1990); bibliographies such as Renner et al. (1938) which covered the literature from 1895 to 1933, Hickey (1977), and Beetle (1954); the National Agricultural Library card catalog covering 1862-1965; Wyoming Range Management Issues (1948-1971); and references in Lauenroth and Laycock (1989). A total of 243 publications outside of $J R M$ was obtained for the period 1895-1990.

The trend in the cumulative number of publications outside of $J R M$ paralleled the trend within $J R M$ during stages 1 and 2 (Fig. 3 ). Articles on range condition appeared prior to the first issue of $J R M$, as is expected if Dyksterhuis' 1949 paper in $J R M$ marks the beginning of stage 2 . The 1961 break in the range condition publications in $J R M$ contrasts with the relatively flat trend at this time in literature published in other sources. The curves separate in the early 1970's, and the 1978-1990 annual average rate of publications on range condition in other sources was 7.5 articles year $^{-1}$ compared to 1.5 in $J R M$ (Fig. 4).

This rise in the 1970's in published articles in sources other than $J R M$ reflects international interest in the concept of range condi-

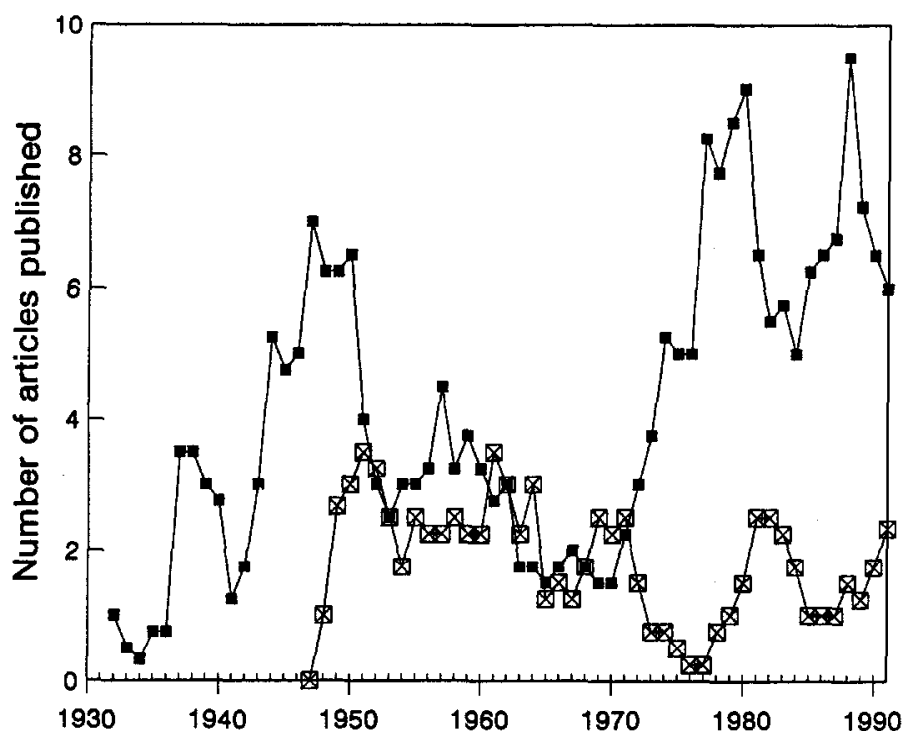

Fig. 4. Number of publications on range condition published in the Journal of Range Management and in other sources, plotted as 3-year moving averages with symbols as in Figure 3 (after Tobey 1981). tion. During the 1961-1969 period, only $3 \%$ of all publications on range condition reported work conducted outside of the United States. During the 1970-1977 and 1978-1990 periods, the percentages were 38 and 36 , respectively. U.S. scientists on sabbaticals or foreign assignments, foreign scientists visiting the United States, and students from foreign countries obtaining advanced degrees in the United States applied the concept of range condition to rangelands in other countries. Many of these international articles paralleled the earlier articles on range condition in the United States, in that some explored the connection between range condition and ecological processes while others described the range condition of an area (Payne et al. 1972, Foran 1973, Demarchi 1973, Lendon et al. 1976, Torres et al. 1978). The First International Rangeland Congress was held in 1978, providing an opportunity for enhanced communication between international scientists.

Slayter (1975) presented 3 reasons why range condition should not be used in arid Australian shrublands. The earliest paper presenting a general critique of the range condition concept was given at the First International Rangeland Congress (Smith 1978). Since then, critiques have attacked 3 assumptions that Smith (1989) identified: (1) climax is pristine vegetation in equilibrium with climate and soil, (2) climax is the only vegetation furnishing adequate soil protection and, therefore, is the most productive species composition for a given site, and (3) retrogression due to grazing stress and succession after removal of that stress are viewed as opposing and reversible linear responses. Scientists presented anomalies in very arid areas with highly erratic precipitation (Westoby 1980), areas dominated by exotic species (Westoby 1980), annual grasslands (Dyksterhuis 1949, Laycock 1991), forested lands (Dyksterhuis 1949, Hall 1978), areas having a long history of use where "climax" vegetation is not known (Westoby et al. 1989), and areas which do not revert to climax when management is removed (Slayter 1975). In addition, scientists faulted the range condition concept for its total dependency on botanical composition (Wilson and Tupper 1982). Lack of an identifiable transition between Stages 3 and 4 in $J R M$ publications may be related to that observation that, with few exceptions, articles critical of range condition have been published outside of $J R M$.

The second and third editions of the range textbooks by Heady (1975) and Stoddart et al. (1975), respectively, were published in 1975, still without reference to papers critical of climax and the successional theories that underlie the range condition concept. Increased criticism coupled with the continued acceptance and use reflect the tensions of Stage 3.

The 1980's saw increasing numbers of workshops and publications critical of the range condition concept. The role of range condition in federal land management was evaluated in a 1980 National Research Council workshop (National Research Council 1984). The Range Inventory Standardization Committee recommended in 1983 that the Society for Range Management not use the "vaguely defined term range condition." Problems with the range succession model were addressed in 4 papers at the 1984 International Rangeland Congress (Westoby et al. 1989). Shortcomings of the range condition concept were addressed in an unpublished symposium at the 1984 meeting of the Ecological Society of America, and in symposia at the 1982, 1985 (Lauenroth and Laycock 1989), and 1992 annual meetings of the Society for Range Management. Foran et al. (1986) described the ecological theory underlying the range condition concept as inadequate. Mentis et al. (1989) described a pardigm shift in South Africa where range science is moving away from equilibrium models.

One indication of the passage to Stage 4 may be the Westoby et al. (1989) description of this "rethinking" of range vegetation dynamics as paralleling the earlier revision of successional theories by community ecologists. While Lauenroth and Laycock (1989) 
both praised and criticized the concept, Scarnechia (1991) criticized the authors for focusing too much on criticisms and not offering an alternative model. Nonequilibrium community dynamics, alternative steady states, and transition thresholds have been offered as components in alternative theoretical models for range vegetation dynamics (Archer and Smeins 1991, Friedel 1991, Laycock 1991). Amidst this criticism is the on-going use of the traditional method of determining range condition by federal agencies (USDA SCS and Iowa State Univ. Statistical Lab. 1987, USDI BLM 1988), and the consequent need to teach this concept to university students who are potential future federal employees, and to retain this concept in research and extension to support range management by federal agencies.

\section{The Potential for Change in the Range Condition Concept}

Lack of change in the range condition concept has been contrasted with progress in ecological theories (Risser 1989). If treated as a theory, the development of the range condition concept differs from the development of the climax theory. Unlike the climax theory, which came to be associated with more researchers than Clements, the range condition concept remains associated with a single scientist, Dyksterhuis. In the climax theory life cycle, highly prolific authors linked a network of institutions. No set of prolific authors represented the invisible college of the range condition field. Only 6 authors published more than 1 article on range condition and no one wrote more than 3 articles on range condition published in $J R M$. No academic institution became the intellectual center for research on range condition, as the University of Nebraska was the intellectual center for climax theory. According to Crane (1972), this absence of a social organization may suggest that the research role was not institutionalized in the discipline. Researchers used range condition as an organizing principle during the 1950's and 1960's, but the lack of a social organization or invisible college may have limited the futher evolution of the theory underlying the range condition concept.

Theories are rejected only when enough anomalies exist that cannot be ignored and an alternative theory is waiting in the wings to replace it. Anomalies have been cited where the assumptions that Smith (1989) identified fail. However, anomalies in the United States, primarily associated with marginal rangelands, are few. Alternative theories also allow the recognition of anomalies (Lightman and Gingerich 1991). International discussions of multiple steady states resulted in a recognition of increasing numbers of anomalies. Still, this accumulation of anomalies based on scientific studies has been insufficient to bring about the universal rejection of the range condition concept.

A research field evolves from the development of an innovation, either a theory or a method (Crane 1972). Clements offered both a new theory and a new method. Dyksterhuis' success also reflects a close tie between a theory, that grazing can influence the succession of a community in a predictable manner, and a method that quantifies differences between the relative species composition of the current vegetation and the climax. Dyksterhuis' method not only allowed extensive areas of rangeland to be assessed reliably, but also allowed management to be prescribed based on the predictable nature of succession and its response to the grazing disturbance. Historical as well as current range institutions have desired to assess the health of rangelands, and while these institutions have differed as to their methodological approaches, this fundamental premise of the predictable nature of succession has guided management.

Standardization of the Dyksterhuis' technique by the SCS caused widespread application, and probably the retention of the concept in teaching and extension. The lack of change in the range condition concept may reflect the lack of flexibility among agency technicians tied to institutionalized methods in contrast to independent researchers. If range condition is treated as technology, then the criteria for rejection, and the motivation for change, may be different than for scientific theories. Ecological theories are not as affected by institutionalization and the entire community can be engaged in the process of refining or evolving the theory/method.

The concept of range condition may evolve along with on-going research within the range community and in other ecological fields (Risser 1989). But this examination of the historical nature of the range condition concept suggests that future innovations will require an underlying theory linked to a field method in order to succeed and be widely accepted. Little attention has been given to the dilemma of applying the alternative theories to management on extensive areas of rangeland. Perhaps the range science community must connect technology to new theory before the range condition concept can be replaced.

\section{Literature Cited}

Albertson, F.W. 1937. Ecology of mixed prairie in west central Kansas. Ecol. Monogr. 7:481-547.

Archer, S., and F.E. Smeins. 1991. Ecosystem-level processes. p. 109-140. In: R.K. Heitschmidt and J.W. Stuth (eds.), Grazing management. Timber Press, Portland, Ore.

Beetle, A.A. 1954. Introductory bibliographies in range management and plant ecology. II. Range management literature 1890-1905. Wyoming Range Manage. 67.

Berg, R.H. 1966. An evaluation of selected Nevada deer ranges: condition, forage potential, and deer-livestock competition. M.S. Thesis, Univ. Nevada, Reno.

Busby, F. 1991. Report on the NAS Rangeland Classification Committee. Annual Meeting Soc. Range Manage., Washington, D.C.

Clark, 1. 1948. Range condition, a classification of the grassland-sagebrush and aspen forage types in the North Bingham Soil Conservation District. USDA SCS, Pacific Coast Region, Portland, Ore.

Clements, F.E. 1905. Research methods in ecology. The University Publishing Co., Lincoln, Neb.

Clements, F.E. 1916. Plant succession: an analysis of the development of vegetation. Carnegie Institution of Washington Pub. 242. Washington, D.C.

Cook, C.W., K. Taylor, and L.E. Harris. 1962. The effect of range condition and intensity of grazing upon daily intake and nutritive value of the diet on desert ranges. J. Range Manage. 15:1-6.

Costello, D.F. 1956. Cover requirements for the protection of range site and biota. J. Range Manage. 9:72-74.

Cowles, H.C. 1911. The causes of vegetative cycles. Bot. Gaz. 51:161-183.

Crane, D. 1972. Invisible colleges: diffusion of knowledge in scientific communities. Univ. Chicago Press.

Demarchi, D.A. 1973. Relationship of range quality to range condition in the Chilcotin Region, British Columbia. J. Range Manage. 26:345-348. Dyksterhuis, E.J. 1949. Condition and management of range land based on quantitative ecology. J. Range Manage. 2:104-115.

Dyksterhuis, E.J. 1958. Ecological principles in range evaluation. Bot. Rev. 24:253-272.

Ellison, L. 1949. The ecological basis for judging condition and trend on mountain rangeland. J. Forest. 47:787-795.

Foran, B.D. 1973. Range condition studies in the Alice Springs District. Turnoff 4:6-8.

Foran, B.D., G. Bastin, and K.A. Shaw. 1986. Range assessment and monitoring in arid lands: the use of classification and ordination in range survey. J. Environ. Manage. 22:67-84.

Forsling, C.L. 1931. A study of the influence of herbaceous plant cover on surface run-off and soil erosion in relation to grazing on the Wasatch Plateau in Utah. USDA Tech Bull. 220. Washington, D.C.

Friedel, M.H. 1991. Range condition assessment and the concept of thresholds: a viewpoint. J. Range Manage. 44:422-426.

GAO. 1982. Rangeland management. More emphasis needed on declined and overstocked grazing allotments. GAO/RCED-88-80. U.S. Government Accounting Office, Gaithersburg, Md.

Gleason, H.A. 1917. The structure and development of the plant association. Bull. Torrey Bot. Club 44:463-481.

Gleason, H.A. 1939. The individualistic concept of the plant association. Amer. Midl. Natur. 21:92-110. 
Goebel, C.J., and C.W. Cook. 1960.Effect of range condition on plant vigor, production, and nutritive value of forage. $J$. Range Manage. 13:307-313.

Hall, F.C. 1978. Applicability of rangeland management concepts to forest-range in the Pacific Northwest. p. 496-499. In: D.N. Hyder (ed.), Proc. First Int. Range. Congr. Soc. Range Manage., Denver, Colo.

Hanson, H., L.D. Love, and M.S. Morris. 1931. Effects of different systems of grazing by cattle upon a western wheat-grass type of range. Colorado Exp. Sta. Bull. 377.

Hanson, C.L., and W.C. Whitman. 1938. Characteristics of major grassland types in western North Dakota. Ecol. Mongr. 8:59-114.

Helms, D. 1990. Conserving the plains: the Soil Conservation Service in the Great Plains. Agr. Hist. 64:58-73.

Heady, H.F. 1975. Rangeland management. 2nd ed. McGraw-Hill Book Co., N.Y.

Hickey, W.C. 1977. A discussion of grazing management systems and some pertinent literature (abstracts \& excerpts) 1895-1966. U.S. Gov. Printing Off. Washington, D.C.

Holechek, J.L. 1981. A brief history of range management in the United States. Rangelands 3:16-17.

Humphrey, R.R. 1949. Field comments on the range condition method of forage survey. J. Range Manage. 2:1-10.

Humphrey, R.R., and P.B. Lister. 1941. Native vegetation as a criterion for determining correct range management and run-off characteristics of grazing lands. J. Forest. 39:837-842.

Laycock, W.A. 1991. Stable states and thresholds of range condition on North American rangelands: a viewpoint. J. Range Manage. 44:427-433.

Lauenroth, W.K., and W.A. Laycock, eds. 1989. Secondary succession and the evaluation of rangeland condition. Westview Press, Boulder, Colo.

Leithead, H.L. 1959. Runoff in relation to range condition in the Big Bend-Davis Mountain section of Texas. J. Range Manage. 12:83-87.

Lendon, C., R.R. Lamacraft, and G. Osmond. 1976. Standards for testing and assessing range condition in central Australia. Aust. Rangeland $\mathrm{J}$. $1: 40-48$.

Lightman, A., and O. Gingerich. 1991. When do anomalies begin? Science 266:690-694.

McArdle, R.E., D.F. Costello, E.E. Birkmaier, C. Ewing, B.A. Hendricks, C.A. Kutzleb, A.A. Simpson, and A.R. Standing. 1936. The white man's toll. Section III. p. 81-1 16. In: The Western Range. Senate Doc. 199, 7th Congress, 2nd Session.

McIntosh, R.P. 1985. The background of ecology. Cambridge Univ. Press, Cambridge, Mass.

Mentis, M.T., D. Grossman, M.B. Hardy, T.G. O'Connor, and P.J. O'Reagain. 1989. Paradigm shifts in South African range science, management and administration. South African J. Sci. 85:684-687.

National Research Council. 1984. Developing strategies for rangeland management. Westview Press, Boulder, Colo.

Nerney, J.J. 1958. Grasshopper infestations in relation to range condition J. Range Manage. 11:247.

Payne, A.L., A. Kubicki, D.G. Wilcox, and L.C. Short. 1972. A report on erosion and range condition in the West Kimberley Area of Western Australia. W. Aust. Dept. of Agr. Tech. Bull, 42. Perth, W. Aust.

Reid, E.H., and G.D. Pickford. 1946. Judging mountain meadow range condition in eastern Oregon and eastern Washington. USDA Circ. 748. Washington, DC.

Renner, F.G., E.C. Crafts, T.C. Hartman, and L. Ellison. 1938. A selected bibliography on management of western ranges, livestock, and wildlife. USDA Misc. Pub. 281. Washington, D.C.

Risser, P.G. 1989. Range condition analysis: past, present, and future. p. 143-155. In: W.K. Lauenroth, and W.A. Laycock (eds.), Secondary succession and the evaluation of rangeland condition. Westview Press, Boulder, Colo.

Sampson, A.W. 1917. Succession as a factor in range management. J. Forest. 15:593-596.

Sampson, A.W. 1919. Plant succession in relation to range management. USDA Bull. 791. Washington, D.C.

Sampson, A.W. 1923. Range and pasture management. John Wiley and Sons, Boston, Mass.
Sampson, A.W. 1952. Range management. John Wiley and Sons, N.Y. Sarvis, J.T. 1920. Composition and density of the native vegetation in the vicinity of the Northern Great Plains Field Station. J. Agr. Res. 19:63-72.

Scarnecchia, D.L. 1991. Review of secondary succession and the evaluation of rangeland condition. J. Range Manage. 44:525.

Seber, G.A.F., and C.J. Wild. 1989. Nonlincar regression. John Wiley and Sons, N.Y.

Shreve, F. 1914. A montane rain-forest: a contribution to the physiological plant geography of Jamaica. Carnegie Institution of Washington Pub. 199. Washington, D.C.

Slayter, R.0. 1975. Structure and function of Australian arid shrublands. p. 66-73. In: D.N. Hyder (ed.), Arid Shrublands-Proc. Third Workshop United States/Australia Rangelands Panel. Soc. Range Manage., Denver, Colo.

Smith, J.G. 1896. Forage conditions of the prairie region, p. 309-324. In: USDA Yearbook of Agriculture-1895. Washington, D.C.

Smith, E.L. 1978. A critical evaluation of the range condition concept. p. 266-267. In:D.N. Hyder (ed.), Proc. First Int. Rangeland Congress, Soc. Range Manage. Denver, Colo.

Smith, E.L. 1989. Range condition and secondary succession: a critique. p. 103-142. In: W.K. Lauenroth, and W.A. Laycock (eds.), Secondary succession and the evaluation of rangeland condition. Westview Press, Boulder, Colo.

Smith, E.L. 1991. Changing directions in range condition assessment. p. 40. In: Abstr. of Papers, Annu. Meeting. Soc. Range Manage., Soc. Range Manage., Denver, Colo.

Spence, L.F. 1938. Range management for soil and water conservation. Utah Juniper 9:18-25.

Stoddart, L.A., and A.D. Smith. 1943. Range management. McGraw-Hill Book Co., N.Y.

Stoddart, L.A., and A.D. Smith. 1955. Range management. 2nd ed. McGraw-Hill Book Co., N.Y.

Stoddart, L.A., A.D. Smith, and T. Box. 1975. Range management. 3rd ed. McGraw-Hill Book Co., N.Y.

Subcommittee on Range Research Methods of the Agricultural Board. 1962. Basic problems and techniques in range research. Pub. 890. Nat. Acad. Sci., Washington, D.C.

Tobey, R. 1981. Saving the prairies: the life cycle of the founding school of American plant ecology, 1895-1955. Univ. California Press, Berkeley.

Torres, G.C. de V., A.P. das Neves, E.J.D. de Pinheiro, and M.C. de Oliveria. 1978. Reproductive performance of zebu cattle raised under range condition in Brazil. Arquivos da Escola de Medicina Veterinaria da Universidade Federal da Bahia 3:112-122.

USDA Forest Serv. 1963. Range research methods. Misc. Pub. 940. U.S. Gov. Print. Off., Washington, D.C.

USDA SCS and Iowa State University Statistical Lab. 1987. Basic statistics: 1982 National Resources Inventory. Stat. Bull. 756. Washington, D.C.

USDI BLM. 1988. Public Land Statistics 1987. Vol, 172. U.S. Gov. Print. Off., Washington, D.C.

U.S. Senate. 1936. The Western Range. Senate Doc. 199. 74th Congress, 2nd Sess. U.S. Gov. Print. Off., Washington. D.C.

Valentine, K.A. 1967. Seasonal suitability, a grazing system for ranges of diverse vegetation types and condition classes. J. Range Manage. 20:395-397.

Wasser, C.H. 1977. Early development of technical range management ca. 1895-1945. Agr. Hist. 51:63-77.

Weaver, J.E., and T.J. Fitzpatrick. 1932. Ecology and relative importance of the dominants of tall-grass prairie. Bot. Gaz. 93:113-50.

Westoby, M. 1980. Elements of a theory of vegetation dynamics in arid rangelands. Israeli J. Bot. 28:169-194.

Westoby, M., B. Walker, and I. Noy-Meir. 1989. Opportunistic management for rangelands not at equilibrium. J. Range Manage. 42:266-274.

Whittaker, R.H. 1953. A consideration of climax theory: the climax as a population and pattern. Ecol. Monogr. 23:41-75.

Wilson, A.D., and G.J. Tupper. 1982. Concepts and factors applicable to the measurement of range condition. J. Range Manage. 35:684-689. 